\title{
Vulnerable Family Members and Income in Chepang Minority
}

\author{
Kishor Atreya*, Narayan Sharma Rimal, Sunita Bhattarai, Sujata Sapkota, \\ Saraswati Adhikari, Jiban Karki, Gerda Pohl \\ PHASE Nepal, Suryabinayak 4, Bhaktapur, Nepal \\ *Correspondence: k.atreya@gmail.com
}

\begin{abstract}
Chepang, an indigenous minority comprising of about $0.26 \%$ of Nepal's population, are 'highly marginalised'. The presence of vulnerable family members such as single women, people with disability and elderly in the Chepang household may further marginalise them. We used 2019 census data of a rural municipality to estimate farm, non-farm and total incomes in the Chepang households' and conducted regressions analysis to identify influencing factors, including the effect of the presence of single women, disability and elderly members on household incomes. The study found that Chepang households were mainly engaged in farms, however, the share of non-farm income was significant. On average, a Chepang individual earned US $\$ 330$ per year. Per capita farm income estimated was US\$120, and that of non-farm was US\$279. Non-farm income was however constrained by the presence of single women and people with disability. The presence of a single woman caused to reduce non-farm income by 13.4\%. Likewise, nonfarm income reduced by $20.5 \%$ when a Chepang household had disabled member. We suggest further studies on vulnerable members, particularly on their health conditions, and access to government services under the changing social, cultural, and environmental conditions.
\end{abstract}

Keywords: Disability, single women, elderly, income, earthquake

JEL Codes: I15 , I32

\section{INTRODUCTION}

Nepal government has recognised 59 indigenous nationalities, altogether comprising of about $35.8 \%$ of the total population of 26.5 million. The Chepang community is one of them, which is about $0.26 \%(68,399)$ of the 2011 Census population (CBS, 2012a), and Nepal Federation of Indigenous Nationalities categorised them as 'highly marginalized'(Piya et al., 2011a). More than $96 \%$ of Chepang communities reside in Central Nepal, mainly Chitwan, Makawanpur, Dhading, and Gorkha districts. Literature suggests drastic change in livelihoods of Chepang in the last century - from a nomadic (hunting wild animals with 'che' - meaning dog, and 'pang' - meaning arrows) to shifting cultivation (farming forested areas in rotations) and to sedentary 
subsistence farming (Piya, Maharjan, Joshi, et al., 2019). Despite this shift, Chepang communities still experience a high degree of poverty, illiteracy, and food insufficiency (Piya, Maharjan, Joshi, et al., 2019); furthermore, they often lack resources, access to government services such as citizenship, health care services and are excluded from development processes. Their own agricultural production is insufficient for a year (Aryal, 2016; Piya et al., 2011b) and often they visit jungles for edible fruits (Sharma \& Aryal, 2016). Improvements in their livelihood has been observed in recent years, for example, their dependency on wild fruits has declined as a result of increasing consumption of market-based non-traditional food items (Piya \& Joshi, 2018). In addition, some of them have initiated income source diversification: labouring skills, raising farm animals, farming vegetables, and working abroad (Piya et al., 2011a; Piya, Maharjan, \& Joshi, 2019). Nonetheless, access to these economic opportunities for Chepang households is still limited.

Further, the presence of family members such as single women, disability and elderly within a household may reduce households' economic wellbeing (Atreya et al., 2020; Goldstein \& Beall, 1986; Mitra et al., 2017; Weiss, 1999). Nepal, being traditionally a patriarchal society, empowerment of women is one of the main issues. Often women have low level of education and technical skills, and suffer from traditions and customary laws, as well as discrimination- altogether compromising economic wellbeing. The situation of women may further worsen if the male counterpart is either deceased/absent, or physically and mentally disable. Studies observed (i) an increasing trend of female-headed households in Nepal, from 12.4\% in 1996 (Pradhan et al., 1997) to 31.3\% in 2016 (Ministry of Health, 2017), and (ii) reducing economic wellbeing in the single women-headed households (Atreya et al., 2020; OXFAM, 2016). Similarly, disability, in any form, may affect household economic wellbeing. Disability refers to difficulties in functioning, activity limitations and participation restrictions (WHO, 2011). Prevalence data on disability though inconsistent in Nepal-1.94\% (CBS, 2012b), 3.6\% (CBS, 2011) and 21.7\% (WHO, 2011) of the total population - it is likely that people with disability under-utilize government and community services even when available for free. It is also possible that people with disability are deprived of education and technical skills, economic participation and employment opportunities, and could be living at high rates of poverty (Dhungana, 2006; Lamichhane \& Okubo, 2014). Further, disabled members may have to bear additional economic burden while purchasing assistive devices, seeking medical care and personal care giver (Bright et al., 2018). Similarly, presence of elderly member in a Chepang household may also compromise economic wellbeing. An increasing trend of elderly population in Nepal has been observed. The size of elderly population in Nepal has been estimated at 2.1 million (8.1\% of the total population) in the national Census 2011. Elderly people have limited access to government support, nutrition opportunity, and additional 
household member may be needed to care of elderly people (Ghimire et al., 2017; Goldstein \& Beall, 1986; Shrestha, 2013; Subedi et al., 2015)- thus may affect household economic wellbeing.

Studying the impact of having a vulnerable member in a minority indigenous community, such as Chepang, is vital because, at one hand Chepang community are 'highly marginalised'; and on the other, the presence of vulnerable family members has the potential to further reduce households' economic wellbeing. Both Chepang households and vulnerable members have minimum capacity to cope with any kind of environmental shock and natural disaster (Duwal et al., 2017; Piya et al., 2011a, 2011b, 2016). Additionally, for indigenous communities of a nation highly prone to natural disasters, such as earthquake and landslide, it is important that possible impact of these environmental disaster is well explored. Disasters make people vulnerable because they damage means of livelihood and access to existing services, marginalizing and disempowering the poorest of the poor (DiCarlo et al., 2018). Studies in Nepal have shown exclusion of the marginalised people from the disaster recovery process, such as reconstruction following the Gorkha earthquake (ACAPS, 2015; Lam \& Kuipers, 2019). An understanding of income sources of the highly marginalized Chepang people and their respective earnings are thus necessary in the changing situation to help develop evidence-based policies and interventions in the recovery period. The objective of this study thus is to analyse Chepang households' farm, non-farm and total incomes and identify their determinants, including the effect of the presence of vulnerable members, particularly that of single women, person with disability and the elderly.

\section{METHODOLOGY}

\section{Study area}

The study was conducted in Gandaki Rural Municipality (GRM, area: $124 \mathrm{~km}^{2}$ ) in the Gandaki province of Nepal (Figure 1), which is very nearby the epicentre of the 2015 earthquake. Gandaki RM lies about $80 \mathrm{~km}$ west of Kathmandu, adjoining a national highway. A recent study in the GRM observed an increase in households by $9 \%$ (total household - 5,763) and population by $28 \%$ (total population - 32,145) compared to the Census 2011. High ethnic diversity characterises the municipality in the province. Chepang constituted $12.3 \%$ of the total households in the municipality (see Table 1 ).

\section{Operational Definition}

For the purpose of this study, single woman has been defined as "a woman who is left with the sole responsibility of parenthood often taking the role of the head of the household, and a woman receiving social security allowances, and not necessarily 
only who is a widow." The Civil Code 2017 provides social security allowances to women under following conditions: (i) aged 60 or more who are divorcee, widow, living separately in legal provision with her husband, and unmarried; and (iii) who are widow at any age.

Elderly has been defined as any person above 60 years old in the Census. Note that elderly aged 70 years and above are only eligible for social security allowance, henceforth this study considered them more vulnerable, and thus accounted in data analysis.

Similarly, people with disability included were those defined in the Nepal's Disability Right Act 2017 - who had long-term physical, mental, intellectual or sensory impairments.

\section{DATA}

In March/April 2019, Practical Help Achieving Self-Empowerment (PHASE) Nepal carried out a census survey in collaboration with GRM under the DFID funded and Mott MacDonald managed "Purnima Programme: Leave No One Behind". The objective of the census was two folds: the first was to identify vulnerable population mainly single women, people with disabilities, elderly, internally displaced persons due to earthquake, and poor and food insecure people; the second was to collect basic household level information to build a baseline foundation for the municipality's longterm planning process.

The census has identified a total of 707 Chepang households in the municipality. Here, we report the census survey data primarily focused on incomes of Chepang households and individuals' vulnerabilities within Chepang households. A total of 685 Chepang households provided incomes from different sources. The amount of money that a household received in return of the services, sales of goods and from investment over the last 12 months was considered. The gross cash income that can be spent (consumed) immediately was included, and own agricultural commodities consumed within household was excluded. For this study, we divided household total income into two categories: farm income \& non-farm income. Ethical approval for this study was received from Nepal Health Research Council (Registered \# 146/2019). Each respondent was informed about the research scope and their right to withhold any information. The person who was responsible for the overall household decision making signed the informed consent and was then interviewed. Census process, methods applied, and data collection tools and techniques are described in detail elsewhere (Atreya et al. 2020). 


\section{DATA ANALYSIS}

Statistical Package for Social Sciences software (SPSS ver. 24 Mac) was used for data analysis. Descriptive statistics and frequency tabulation are provided. Linear regression was used to identify factors determining farm, non-farm and total incomes. The dependent variables (farm, non-farm and total incomes) were highly skewed (a large majority on the low-income side), assumption of normality violated, so logtransformed. We arrived at a robust equation using "enter" method primarily for total income, especially considering the significant determinants, vulnerable members, and our understanding of literature. Once determinants were identified for the total income, we looked at the effect of the same factors on farm and non-farm incomes. Regression coefficients were transformed back (antilog) for interpretable results. The $\%$ change in incomes $\left(\mathrm{y}_{\mathrm{i}}\right)$ by one-unit change in independent variables $\left(\mathrm{k}_{\mathrm{j}}\right)$ were estimated by exponentiating the respective coefficient $\left(\S_{\mathrm{ij}}\right)$ following Eq. 1.

$\%$ change in $y_{i}=\left(e^{\beta_{i j}}-1\right) * 100$

The statistical test was done at the $95 \%$ confidence level. The factors determining household incomes and their expected hypothesis are provided in Table 2. We used elderly aged 70 years and above in the regression model because they are more vulnerable, and there is high chance of productivity loss of care-taker in a household.

\section{RESULTS}

\section{Respondent and household characteristics}

Respondents and households' characteristics are provided in Table 3 and Table 4 respectively. Females constituted $43 \%$ of total respondents. The average age of the respondents was 41 years. Nearly $70 \%$ of respondents identified agriculture as their main occupation followed by labour wage (21\%) and job (5\%). Approximately $28 \%$ respondents were illiterate - not able to read and write at all, and in addition $24 \%$ of respondents never attended schools but reported being able to read and write. Very few $(3 \%)$ respondents had completed Grade 10 of schooling.

Many of the Chepang households (98.4\%) owned agricultural land (see Table 4). They also leased-in agricultural land (12.4\%) for crop production. About $91 \%$ of households raised farm animals such as goat, chicken, and cattle. Approximately $18 \%$ of the Chepang households in the study area are yet to connect in national electricity grid line, whereas nearly half of the households (47\%) had no access to tap water. One in four Chepang household used Liquid Petroleum (LP) gas for cooking, and only 32\% of them had television set. Approximately 25\% of Chepang household contained elderly 
people aged 60 years and above, 11\% contained single women, and $6 \%$ contained people with disability.

\section{Household Income}

Household income from various sources along with descriptive statistics is provided in Table 5. Many households reported cash earnings from vegetable sales (58\%), labour wage (56\%) and livestock sales (56\%). Very few households received incomes from the sale of non-timber forest products $(<1 \%)$, dairy product $(1 \%)$, and cereal crops $(3 \%)$. A total of 528 households (77\%) received cash from farm sources and 582 households $(85 \%)$ from non-farm sources. Many Chepang households stated cultivating farmland (>98\%) and raising livestock (91\%), however, cash earnings from these sources was limited to nearly half of the Chepang households. The households' annual farm income was US\$607 (median \$318). Median income from the sale of vegetables and livestock were $\$ 273$ and 145, respectively. Likewise, households' annual non-farm income was \$1406 (median \$ 909). Average earning from job was the highest, followed by remittance, and non-farm business; however, few households received earnings from job (16\%), remittance (11\%), and non-farm business $(4 \%)$.

Per capita farm income estimated was $\$ 120$, and that of non-farm was $\$ 279$ (Table 6). Income from vegetable sale comprised $76 \%$ of the farm income, and $40 \%$ of the total income. In the $10 \%$ of the households, vegetable sale was the only source of household income. Similarly, share of livestock income to the farm income was $58 \%$, and that of total income was $22 \%$. About $5 \%$ of total households were totally (100\%) dependent on livestock for household income. Daily wage, on the other hand, contributed $86 \%$ of the non-farm income and $63 \%$ of the total income (see Table 7 ). More than $20 \%$ of households had no other income sources than daily wage labour.

\section{Income Determinants}

Descriptive statistics of household income determinants are given in Table 8. Chepang households, on average, consisted of equal number of male and female members. Approximately $17 \%$ had at least one senior member aged 70 years and above. About $13 \%$ of the households had leased-in agricultural land for crop cultivation. Chepang households had diversified income sources - ranged from a minimum of one to at maximum six income sources.

As previously mentioned, dependent variables are log-transformed and marginal effects were estimated following Eq. 1. The regression analysis (Table 9) revealed that age of household head (AGE), households with vulnerable members such as single women (SW), disability (PWD), and elderlies aged 70 years and above (ELD70); 
and leased in agricultural land (AGRILEASE) negatively determines households' total income. The negative association of SW, PWD and ELD70 on the household total income were, however, statistically non-significant at the 95\% confidence level. Likewise, number of male (MALE) and female (FEMALE) household members, number of income sources (INSOURCE) and the LPG (proxy for "economic status") were found positively and significantly associated with household total income. For the farm income, the directions of the association (sign of the coefficients) were similar (except PWD and AGRILEASE) and only two determinants (INSOURSE and LPG) were found significant at the 95\% confidence level. Similarly, for the non-farm income, the directions of association are almost similar to that of total incomes, however, AGE and AGRILEASE were found statistically non-significant, and interestingly SW and PWD were found statistically significant at the 5\% confidence level. ELD70 was negative and non-significant for all the income categories.

The analysis, interestingly also revealed that, when a Chepang household leased-in agriculture land, it could add minimum amount $(3.4 \%)$ to the farm income $(p>0.05)$, however it significantly $(\mathrm{p}<0.05)$ decreases household total income by $9.1 \%$ (see Table 10). Similarly, when a household member is disabled, result showed positive but nonsignificant association ( $p>0.05)$ on the farm income, however disability was found to be significantly decreasing non-farm income $(p<0.05)$ by $20.5 \%$.

\section{DISCUSSIONS}

This study found that the presence of vulnerable family members such as single women, people with disability, and elderly aged 70 years and above can reduce income in the Chepang households. Agriculture and local labour market were the main sources of income for Chepang households. Most of them received cash from vegetable sales, labour wage and livestock sales; and very few Chepang households received cash from skilled job, remittance and non-farm business. It is evident that Chepang community were more dependent on farm activities, which, however, contributed less to the total household income, compared to those who reported earnings from labour, remittance, and skilled jobs. A higher per capita median earning from the non-farm sources (\$170) compared to that from farm sources (\$64) was observed (see Table 6). However, incomes from vegetable and livestock sales contributed to about $76 \%$ and $58 \%$ of the farm incomes, respectively. We further observed that a few Chepang households had no other sources of income other than vegetable sale $(10 \%)$, and livestock sale $(5 \%)$. This indicates a need to continue vegetable farming and livestock raising activities for the survival of poorest of the poor Chepang households who are deprived of other non-farm income sources. 
The median earning of the Chepang household was calculated at US\$455, mainly from daily wage labour. About $20 \%$ of the Chepang households solely depended on unskilled wage earning. The share of daily wage to the household total income was about $63 \%$. This is in fact enormous contribution, indicating their active participation in local labour market. Development organisations, local government bodies, and National Reconstruction Authority (NRA) offered unskilled and skilled labour/job opportunities immediately after the Gorkha earthquake. Accordingly, they provided a number of skill trainings. During the study time, reconstruction of nearly $72 \%$ of the houses in the municipality had been fully completed, so it is likely that present labour demand may have been reduced-possibly a sharp decline in income from wage labour. This indicates a need of intervention for those Chepang households who will be out of local labour market in the recent future. Probably, establishing a synergy between farm and non-farm income sources and providing skills enhancing trainings may be vital for them. For example, providing trainings on vegetable/livestock farming, and establishing linkages with local cooperatives for vegetable/livestock marketing could be one option. Institutionalization of the very poor sector of the society through establishing cooperatives helps them not only in product sales, but also make them resilient during climatic shock if the established institution is closed tied up with other institutions, for example local body, bank and finance, and other service providers.

A number of factors were found to be affecting Chepang households' farm, nonfarm and total income. In the regression analysis, we observed that as the age of the household head increases by 1 year, the total income reduced by $0.4 \%$, this is because younger individuals likely to prefer non-farm activities (McNamara \& Weiss, 2005). Increase in the number of household members (any gender) increases total income, perhaps through non-farm activities. An increase in neither the male nor the female members in the Chepang household cause a significant increase in farm income. Perhaps because of cultivating on the low productive and marginalised farm land, and availability of off-farm income opportunities, they may face acute labour shortage on their farm. We observed reduced non-farm income when the Chepang household contained vulnerable members. For example, the presence of a single woman caused to reduce non-farm income by $13.4 \%$. Likewise, non-farm income reduced by $20.5 \%$ when a household possessed disabled member. The effect of elderly aged $\geq 70$ years on the non-farm income was statistically not significant at the $95 \%$ confidence level. Total household income decreased by $9.1 \%$ when a Chepang household leased-in agricultural land. We did not observe significant increase in farm income despite leased-in land. Chepang households may lease-in additional land when they have no other income options and use it mainly for subsistence. Income source diversification was found vital; this could depend on household's income gradients, for example, richer households diversify non-farm income, whereas poorer households diversify 
farm income (Omotayo, 2016). Finally, existing 'economic status' had positive effect on household incomes, illustrated by significantly higher income in the households who used LPG for cooking.

The findings of this study raise a number of policy implications. The study showed that both farm and non-farm incomes are equally important for Chepang households, however, the linkages between income sources are missing, so policy that establish synergy between both farm and non-farm income sources is needed. This is because, most of the non-farm income may be used for consumption, and farm production is hardly sufficient. An increasing trend of vulnerable population in our society has been observed, and their presence may affect household wellbeing - so priority should be given on raising awareness on issues of vulnerable population by highlighting their rights, health conditions, and access to social security provisions including special allowances - otherwise deprivation from these may push such households into deeper poverty. Studies have shown that social security allowances positively contributed to the economic wellbeing and health of recipients (Banks et al., 2019; Roelen \& Chhetri, 2016). Increasing access to employment opportunities through individual tailored interventions and market potentials and establishing sustainable linkages of vulnerable groups with local governments and private sectors could be a few strategies for reducing poverty in vulnerable households as well as increasing their resilience to any kind of environmental shocks. Diversification of income sources increased incomes in the study population; thus, development strategies need to consider livelihood enhancing interventions in such a way that it has local demand, social acceptance and generates positive effects on wellbeing. Additionally, the development models should shift from - from "reaching many" and "technology transfer" towards "reaching local for sustainable system change" (Woltering et al., 2019). For example, instead of just providing assistive devices to people with disabilities, it would be better to institutionalise them and establish their linkages with public and private service providers and rehabilitation centres for building more resilient society. Likewise, instead of just providing a goat, or chicken, or vegetable seed kits to poor farmers, it would be better in addition to link them with agricultural service providers, agrovets, financial services, insurance company and so on.

A few limitations of this study are notable. Incomes are self-reported, and some respondents may have been reluctant to reveal their income sources and respective incomes. This study accounted for immediate cash of the earthquake affected households, so future income dynamics in the study area may be different, and the study findings may not be comparable with non-earthquake affected areas. This study, however, showed that both farm and non-farm incomes are equally vital to the marginalized Chepang household's, and their economic wellbeing reduced when 
households had vulnerable family members, henceforth, suggested to safeguard health and social systems of the country to adjust increasing population of vulnerable members in Nepal.

\section{CONCLUSION}

Chepang households were mainly engaged in farms, however, the share of non- farm income to the household total earnings was significant. The sales of vegetables and farm animals were the major sources of farm income; whereas daily labour wage was the main non-farm income source. Earning from non-farm sources is however constrained by the presence of single women and people with disabilities in the Chepang household. Diversification of income sources increases household economic wellbeing. More studies on vulnerable members, particularly on their health conditions and access to social security services are recommended.

\section{Acknowledgement}

Funding and logistic supports received from the UK Department of International Development (DFID), Mott McDonald and Gandaki Rural Municipality are highly acknowledged. Thanks to Anjan Pokharel and Ganga Adhikari for helping in the Census survey and data validation. Authors also thank enumerators and people of municipality.

\section{Conflict of Interest}

The authors have no conflict of interests. The views and opinions presented here are those of the authors, and do not reflect the views of support agencies and collaborators.

\section{REFERENCES}

ACAPS. (2015). Lessons learned for Nepal earthquake response (Issue October 2010). https:// www.alnap.org/system/files/content/resource/files/main/l-acaps-lessonslearned-nepal-earthquake-27-april-2015.pdf

Aryal, B. (2016). State of food (in)Security in Chepang community: A case of Dahakhani VDC, Chitwan. Economic Literature, 11, 60. https://doi.org/10.3126/ el.v11i0.14868

Atreya, K., Sharma, N., Makai, P., Baidya, M., Jiban, K., Pohl, G., \& Bhattarai, S. (2020). Sources and determinants of income in Dalit households in Gorkha, Nepal. GeoJournal, Revised and re-submitted.

Banks, L. M., Walsham, M., Neupane, S., Neupane, S., Pradhananga, Y., Maharjan, M., Blanchet, K., \& Kuper, H. (2019). Access to social protection among people 
with disabilities: Mixed methods research from Tanahun, Nepal. European Journal of Development Research, 31(4), 929-956. https://doi.org/10.1057/s41287019-0194-3

Bright, T., Wallace, S., \& Kuper, H. (2018). A systematic review of access to rehabilitation for people with disabilities in low-and middle-income countries. International Journal of Environmental Research and Public Health, 15(10), 1-34. https:/doi. org/10.3390/ijerph15102165

CBS. (2011). Nepal living standard survey report Volume-I.

CBS. (2012a). National population and housing census 2011. Volume 01, NPHC 2011 (National Report) Government of Nepal, National Planning Commission Secretariat, Central Bureau of Statistics, Kathmandu. http://cbs.gov.np/image/ data/Population/VDC-Municipality in detail/35 Chitwan_VDCLevelReport. pdf

CBS. (2012b). National Population and Housing Census 2011 (Major Highlights).

Dhungana, B. M. (2006). The lives of disabled women in Nepal: Vulnerability without support. Disability and Society, 21(2), 133-146. https://doi. org/10.1080/09687590500498051

DiCarlo, J., Epstein, K., Marsh, R., \& Måren, I. (2018). Post-disaster agricultural transitions in Nepal. Ambio, 47(7), 794-805. https://doi.org/10.1007/s13280018-1021-3

Duwal, S., Neupane, P. K., Devkota, B., \& GC, Y. D. (2017). Climate change imprint and impacts on livelihood of indigenous nationalities: A case of Chepang community from Bhumlichowk area, Gorkha district, Nepal. International Journal of Sciences: Basic and Applied Research, 35(3), 173-183.

Ghimire, S., Baral, B. K., \& Callahan, K. (2017). Nutritional assessment of community dwelling older adults in rural Nepal. PLoS ONE, 12(2), 1-15. https://doi. org/10.1371/journal.pone.0172052

Goldstein, M., \& Beall, C. (1986). Family change, caste, and the elderly in a rural locale in Nepal. Journal of Cross-Cultural Gerontology I, 1, 305-316.

Lam, L. M., \& Kuipers, R. (2019). Resilience and disaster governance: Some insights from the 2015 Nepal earthquake. International Journal of Disaster Risk Reduction, 33(November 2018), 321-331. https://doi.org/10.1016/j.ijdrr.2018.10.017

Lamichhane, K., \& Okubo, T. (2014). The nexus between disability, education, and employment: Evidence from Nepal. Oxford Development Studies, 42(3), 439453. https://doi.org/10.1080/13600818.2014.927843 
McNamara, K. T., \& Weiss, C. (2005). Farm household income and on- and off-farm diversification. Journal of Agricultural and Applied Economics, 37(1), 37-48. https://doi.org/10.1017/s1074070800007082

Ministry of Health, N. N. E. and I. (2017). Nepal demographic and health survey 2016. In Kathmandu Nepal: Ministry of Health, Nepal. https://doi.org/10.1007/b138909

Mitra, S., Palmer, M., Kim, H., Mont, D., \& Groce, N. (2017). Extra costs of living with a disability: A review and agenda for research. In Disability and Health Journal, 10, (4), 475-484. Elsevier. https://doi.org/10.1016/j.dhjo.2017.04.007

Morgan, T. (2018). The socioeconomic impact of switching to LP gas for cooking: A report to the world LPG association. https://www.wlpga.org/wp-content/uploads/2018/10/ WLPGA-Socioeco-Impact-Update-2018-V1-PbP.pdf

Omotayo, A. O. (2016). Economic synergy between rural off-farm income and households' poverty in Ekiti state, Nigeria. Journal of Human Ecology, 56(1-2), 99-106. https://doi.org/10.1080/09709274.2016.11907043

OXFAM. (2016). "I am alone": Single women and the Nepal earthquake. https://www.oxfam. org/en/research/i-am-alone-single-women-and-nepal-earthquake

PHASE Nepal. (2019). Household survey report: Gandaki rural municipality, Gorkha.

Piya, L, \& Joshi, N. P. (2018). Food basket of a highly marginalized indigenous community in the mid-hills of Nepal: Transition and responsible factors. 30th International Conference of Agricultural Economists, 1-16.

Piya, L., Joshi, N. P., \& Maharjan, K. L. (2016). Vulnerability of Chepang households to climate change and extremes in the Mid-hills of Nepal. Climatic Change, 135(3-4), 521-537. https://doi.org/10.1007/s10584-015-1572-2

Piya, L., Maharjan, K., \& Joshi, N. (2011a). Forest and food security of indigenous people : A case of Chepangs in Nepal. Journal of International Development and Cooperation, 17(1), 113-135. https://doi.org/10.15027/31345

. (2011b). Livelihood strategies of indigenous nationalities in Nepal : A case of Chepangs. Journal of International Development and Cooperation, 17(2), 99-113. https://doi.org/10.15027/31354

- (2019). Socio-economic issues of climate change: A livelihood analysis from Nepal. In Socio-Economic Issues of Climate Change: A Livelihood Analysis from Nepal. Springer Singapore. https://doi.org/10.1007/978-981-13-5784-8

. (2019). Chepangs: The community in focus. In Socio-Economic Issues of Climate Change (pp. 61-67). Springer Nature. https://doi.org/10.1007/978-981-13-57848 _5 
Pradhan, A., Aryal, R. H., Regmi, G., Ban, B., \& Govindasamy, P. (1997). Nepal family health survey, 1996. https://doi.org/10.1007/SpringerReference_29880

Roelen, K., \& Chhetri, H. (2016). Social protection's response to child poverty and vulnerability in Nepal. https://www.ids.ac.uk/files/dmfile/SCNepalIDSpaper2016Final.pdf

Sharma, G., \& Aryal, B. (2016). Household economies of Chepang people in Chitwan. Economic Literature, 13, 39-45. https://doi.org/10.3126/el.v13i0.19149

Shrestha, L. (2013). Geriatric health in Nepal: Concerns and experience. Nepal Medical College Journal : NMCJ, 15(2), 148-152. http://www.ncbi.nlm.nih.gov/ pubmed/24696938

Subedi, Y. P., Marais, D., \& Newlands, D. (2015). Where is Nepal in the nutrition transition? Asia Pac J Clin Nutr, 155-166.

Weiss, L. (1999). Single women in Nepal: Familial support, familial neglect. Journal of Comparative Family Studies, 30(2), 243-256.

WHO. (2011). World report on disability. In World Health Organization. World Health Organization.

Woltering, L., Fehlenberg, K., Gerard, B., Ubels, J., \& Cooley, L. (2019). Scaling - from "reaching many" to sustainable systems change at scale: A critical shift in mindset. Agricultural Systems, 176. https://doi.org/10.1016/j.agsy.2019.102652 


\section{List of Tables}

Table 1. Ethnic Composition in Gandaki Rural Municipality, Nepal

\begin{tabular}{|l|l|l|}
\hline Caste/Ethnicity & Household & Percent \\
\hline Brahmin/Chhetri/Thakuri & 1439 & $24.97 \%$ \\
\hline Magar & 1054 & $18.29 \%$ \\
\hline Dalit & 826 & $14.33 \%$ \\
\hline Gurung & 808 & $14.02 \%$ \\
\hline Newar & 765 & $13.27 \%$ \\
\hline Chepang & 707 & $12.27 \%$ \\
\hline Other & 164 & $2.85 \%$ \\
\hline Total & $\mathbf{5 7 6 3}$ & $\mathbf{1 0 0} \%$ \\
\hline Source: PHASE Nepal (2019) & & \\
\hline
\end{tabular}

Table 2. Determinants of Household Incomes and Expected Hypothesis

\begin{tabular}{|c|c|c|c|c|}
\hline \multirow[b]{2}{*}{ Determinants } & \multirow[b]{2}{*}{ Explanation } & \multicolumn{3}{|c|}{ Expected hypothesis } \\
\hline & & Total & Farm & $\begin{array}{l}\text { Non - } \\
\text { farm }\end{array}$ \\
\hline AGE & $\begin{array}{l}\text { Age of the respondents. Higher the age lower will } \\
\text { be the total income, because older individuals are } \\
\text { less likely to engage in multiple income sources, } \\
\text { and younger individuals prefers non-farm } \\
\text { activities. }\end{array}$ & - & + & - \\
\hline MALE & $\begin{array}{l}\text { Total number of male household members. } \\
\text { Higher male members in the households likely } \\
\text { to increase overall household incomes, both farm } \\
\text { and non-farm - because they are earners in rural } \\
\text { society. }\end{array}$ & + & + & + \\
\hline FEMALE & $\begin{array}{l}\text { Total number of female household members. } \\
\text { Higher female members in the households likely } \\
\text { to increase farm income because of increased } \\
\text { responsibility in farm activities (agricultural } \\
\text { feminisation). }\end{array}$ & + & + & - \\
\hline SW & $\begin{array}{l}\text { Household with single women (if YES } 1 \text {, } 0 \\
\text { otherwise). Increased risk of discrimination and } \\
\text { labour constraint; overall negatively affecting } \\
\text { incomes. }\end{array}$ & - & - & - \\
\hline PWD & $\begin{array}{l}\text { Household with disability (if YES 1, } 0 \text { otherwise). } \\
\text { Acute labour shortage, productivity loss, and } \\
\text { additional care giver needed, resulting minimal } \\
\text { incomes. }\end{array}$ & - & - & - \\
\hline
\end{tabular}




\begin{tabular}{|l|l|l|l|l|}
\hline ELD70 & $\begin{array}{l}\text { Household with elder 70 years and above (if YES } \\
\text { 1, 0 otherwise). Low human productivity due to } \\
\text { increased risk of illness and injury, ageing effect, } \\
\text { and additional caregiver - resulting minimal } \\
\text { incomes. }\end{array}$ & - & - \\
\hline AGRILEASE & $\begin{array}{l}\text { Household leased in agricultural land (if YES 1; } \\
\text { 0 otherwise) for crop production. Incomes from } \\
\text { leased-in agricultural land is an addition to the } \\
\text { household's farm and total incomes. }\end{array}$ & + & - \\
\hline INSOURCE & $\begin{array}{l}\text { Number of income sources (out of 10). Income } \\
\text { diversification increases household incomes. }\end{array}$ & + & + & + \\
\hline LPG & $\begin{array}{l}\text { Household using LPG for cooking (if YES 1, } \\
0 \text { otherwise) It indicates better “economic } \\
\text { status", than who does not use, thus is a proxy } \\
\text { of economic wellbeing. Increase in income tends } \\
\text { to shift traditional fuels to modern fuels like LPG } \\
\text { for cooking in developing countries (Morgan, } \\
\text { 2018) }\end{array}$ & + & + & + \\
\hline
\end{tabular}

Table 3. Respondent Characteristics of the Chepang Households $(\mathrm{N}=707)$

\begin{tabular}{|l|l|}
\hline Percentage of female respondents & $43 \%$ \\
\hline Percentage of male respondents & $57 \%$ \\
\hline Average age of the respondents & 41.1 \\
\hline Main Occupation \% & 69.7 \\
\hline Agriculture & 20.8 \\
\hline Labour wage & 4.9 \\
\hline Job & 2.0 \\
\hline Foreign employment & 1.3 \\
\hline Business & 1.3 \\
\hline Student & \multicolumn{2}{|l|}{} \\
\hline Education level \% & 28.3 \\
\hline Can't read/write & 23.8 \\
\hline Informal education & 30.9 \\
\hline Primary (1-5) & 14.0 \\
\hline Secondary (6-10) & 1.9 \\
\hline Higher secondary (11-12) & 1.2 \\
\hline Bachelor &
\end{tabular}


Table 4. Chepang Household Characteristics

\begin{tabular}{|l|l|l|l|}
\hline \multirow{2}{*}{ Characteristics } & Response & Count & $\%$ \\
\hline \multirow{2}{*}{ Leased in cultivable land } & Yes & 696 & $98.4 \%$ \\
\cline { 2 - 4 } & No & 11 & $1.6 \%$ \\
\hline \multirow{2}{*}{ Raise livestock } & Yes & 88 & $12.4 \%$ \\
\cline { 2 - 4 } & No & 619 & $87.6 \%$ \\
\hline \multirow{2}{*}{ Access to electricity } & Yes & 643 & $90.9 \%$ \\
\cline { 2 - 4 } & No & 64 & $9.1 \%$ \\
\hline \multirow{2}{*}{ Access to tap water } & Yes & 584 & $82.6 \%$ \\
\cline { 2 - 4 } & No & 123 & $17.4 \%$ \\
\hline \multirow{2}{*}{ LP gas for cooking } & Yes & 376 & $53.2 \%$ \\
\cline { 2 - 4 } & No & 331 & $46.8 \%$ \\
\hline \multirow{2}{*}{ Television } & Yes & 175 & $24.8 \%$ \\
\cline { 2 - 4 } & No & 532 & $75.2 \%$ \\
\hline Family members aged 60 years and above & Yes & 223 & $31.5 \%$ \\
\cline { 2 - 4 } & No & 484 & $68.5 \%$ \\
\cline { 2 - 4 } & No & 178 & $25.2 \%$ \\
\hline Single women & Yes & 529 & $74.8 \%$ \\
\hline & No & 629 & $11.0 \%$ \\
\hline Disability & Yes & $49.0 \%$ \\
\cline { 2 - 4 } & No & 667 & $94.3 \%$ \\
\hline & & & \\
\hline
\end{tabular}


Table 5. Annual Household Incomes (US\$) [1US\$ = 110 NRs)

\begin{tabular}{|l|l|l|l|l|l|l|l|}
\hline Income sources & $\begin{array}{l}\text { Number of } \\
\text { households }\end{array}$ & No & Min & Max & Mean & Median & $\begin{array}{l}\text { Std. Dev. } \\
\text { Mean }\end{array}$ \\
\hline Vegetable crop sales & 395 & $58 \%$ & 9 & 4545 & 572 & 273 & 809 \\
\hline Wage labour & 385 & $56 \%$ & 45 & 5455 & 926 & 455 & 1039 \\
\hline Livestock sales & 383 & $56 \%$ & 18 & 7273 & 237 & 145 & 540 \\
\hline Pension/social security & 132 & $19 \%$ & 18 & 9273 & 426 & 218 & 890 \\
\hline Job & 107 & $16 \%$ & 91 & 11564 & 2013 & 1545 & 1585 \\
\hline Remittance & 78 & $11 \%$ & 182 & 13636 & 1978 & 1818 & 1779 \\
\hline $\begin{array}{l}\text { Business other than } \\
\text { agriculture }\end{array}$ & 30 & $4 \%$ & 73 & 5455 & 1176 & 773 & 1362 \\
\hline Cereal crop sales & 23 & $3 \%$ & 18 & 1818 & 148 & 45 & 368 \\
\hline Milk \& milk product sales & 9 & $1 \%$ & 36 & 91 & 52 & 45 & 17 \\
\hline NTFPs sales & 2 & $<1 \%$ & 12 & 182 & 97 & 97 & 120 \\
\hline Farm & 528 & $77 \%$ & 9 & 9091 & 607 & 318 & 904 \\
\hline Non-farm & 582 & $85 \%$ & 12 & 16145 & 1406 & 909 & 1801 \\
\hline Total & 685 & $100 \%$ & 22 & 23418 & 1662 & 1000 & 2096 \\
\hline
\end{tabular}

Table 6. Per Capita Income Disaggregated by Farm and Non-Farms (US\$)

\begin{tabular}{|l|l|l|l|l|l|}
\hline Income category & Min & Max & Mean & Median & Std. Deviation of Mean \\
\hline Farm & 2.27 & 1298.70 & 120.25 & 64.29 & 163.20 \\
\hline Non-farm & 2.95 & 2727.27 & 278.96 & 170.45 & 328.61 \\
\hline Total & 7.58 & 2727.27 & 329.70 & 212.12 & 362.76 \\
\hline
\end{tabular}

Table 7. Share of Vegetable Sale, Livestock Sale and Daily Wages on Income Category

\begin{tabular}{|l|l|l|l|}
\hline Income category & Vegetable sales & Livestock sales & Daily wage \\
\hline Farm & $75.6 \%$ & $58.2 \%$ & - \\
\hline Non-farm & - & - & $86.2 \%$ \\
\hline Total & $39.8 \%$ & $22.2 \%$ & $62.9 \%$ \\
\hline
\end{tabular}


Table 8. Descriptive Statistics of Household Income Determinants

\begin{tabular}{|l|l|l|l|l|}
\hline Determinants & Min & Max & Mean & Standard deviation \\
\hline AGE & 15 & 95 & 40.85 & 16.52 \\
\hline MALE & 0 & 9 & 2.61 & 1.29 \\
\hline FEMALE & 0 & 8 & 2.58 & 1.43 \\
\hline SW & 0 & 1 & 0.11 & 0.31 \\
\hline PWD & 0 & 1 & 0.06 & 0.23 \\
\hline ELD70 & 0 & 1 & 0.17 & 0.37 \\
\hline AGRILEASE & 0 & 1 & 0.13 & 0.33 \\
\hline INSOURCE & 1 & 6 & 2.25 & 0.99 \\
\hline LPG & 0 & 1 & 0.25 & 0.43 \\
\hline
\end{tabular}

Table 9. Results of Linear Regression Analysis (Dependent Variables Are Log-Transformed)

\begin{tabular}{|c|c|c|c|c|c|c|c|c|c|c|c|c|}
\hline \multirow[t]{3}{*}{ Determinants } & \multicolumn{4}{|c|}{ TOTAL income } & \multicolumn{4}{|c|}{ FARM income } & \multicolumn{4}{|c|}{ NON-FARM income } \\
\hline & \multicolumn{2}{|c|}{\begin{tabular}{|l|} 
Unstandardized \\
Coefficients \\
\end{tabular}} & \multirow[t]{2}{*}{$\mathrm{t}$} & \multirow[t]{2}{*}{ Sig. } & \multicolumn{2}{|c|}{$\begin{array}{l}\text { Unstandardized } \\
\text { Coefficients }\end{array}$} & \multirow[t]{2}{*}{$t$} & \multirow[t]{2}{*}{ Sig. } & \multicolumn{2}{|c|}{$\begin{array}{l}\text { Unstandardized } \\
\text { Coefficients }\end{array}$} & \multirow[t]{2}{*}{$t$} & \multirow[t]{2}{*}{ Sig. } \\
\hline & B & $\begin{array}{l}\text { Std. } \\
\text { Error }\end{array}$ & & & B & $\begin{array}{l}\text { Std. } \\
\text { Error }\end{array}$ & & & B & $\begin{array}{l}\text { Std. } \\
\text { Error }\end{array}$ & & \\
\hline Constant & 2.458 & 0.059 & 41.343 & 0.000 & 2.094 & 0.085 & 24.772 & 0.000 & 2.582 & 0.077 & 33.406 & 0.000 \\
\hline AGE & -0.004 & 0.001 & -3.521 & 0.000 & -0.002 & 0.001 & -1.554 & 0.121 & -0.002 & 0.001 & -1.630 & 0.104 \\
\hline MALE & 0.041 & 0.012 & 3.353 & 0.001 & 0.015 & 0.015 & 0.948 & 0.344 & 0.060 & 0.016 & 3.861 & 0.000 \\
\hline FEMALE & 0.024 & 0.011 & 2.186 & 0.029 & 0.025 & 0.014 & 1.833 & 0.067 & 0.032 & 0.014 & 2.285 & 0.023 \\
\hline SW & -0.097 & 0.05 & -1.928 & 0.054 & -0.061 & 0.067 & -0.913 & 0.362 & -0.144 & 0.064 & -2.263 & 0.024 \\
\hline PWD & -0.062 & 0.068 & -0.916 & 0.360 & 0.016 & 0.083 & 0.188 & 0.851 & -0.229 & 0.088 & -2.612 & 0.009 \\
\hline ELD70 & -0.04 & 0.045 & -0.886 & 0.376 & -0.07 & 0.057 & -1.232 & 0.218 & -0.056 & 0.056 & -0.993 & 0.321 \\
\hline AGRILEASE & -0.095 & 0.045 & -2.100 & 0.036 & 0.033 & 0.054 & 0.609 & 0.543 & -0.037 & 0.063 & -0.579 & 0.563 \\
\hline INSOURCE & 0.21 & 0.016 & 12.949 & 0.000 & 0.145 & 0.023 & 6.449 & 0.000 & 0.053 & 0.021 & 2.479 & 0.013 \\
\hline LPG & 0.248 & 0.035 & 7.088 & 0.000 & 0.155 & 0.044 & 3.527 & 0.000 & 0.286 & 0.046 & 6.244 & 0.000 \\
\hline Model summary & \multicolumn{4}{|c|}{$\begin{array}{l}\mathrm{N}=672, \mathrm{R}^{2}=0.327, \text { Adjusted } \\
\mathrm{R}^{2}=0.318, \text { Standard Error of } \\
\text { Estimate }=0.387, \mathrm{~F} \text { test }=35.834 \\
\mathrm{p}<0.001\end{array}$} & \multicolumn{4}{|c|}{$\begin{array}{l}\mathrm{N}=519, \mathrm{R}^{2}=0.132, \text { Adjusted } \\
\mathrm{R}^{2}=0.117, \text { Standard Error of } \\
\text { Estimate }=0.437, \mathrm{~F} \text { test }=8.610 \\
\mathrm{p}<0.001\end{array}$} & \multicolumn{4}{|c|}{$\begin{array}{l}\mathrm{N}=571, \mathrm{R}^{2}=0.151, \text { Adjusted } \mathrm{R}^{2}= \\
0.137, \text { Standard Error of Estimate } \\
=0.464, \mathrm{~F} \text { test }=11.103, \mathrm{p}<0.001\end{array}$} \\
\hline
\end{tabular}


Table 10. Estimated Marginal effects (\%) of Determinants

\begin{tabular}{|c|c|c|c|}
\hline \multirow[t]{2}{*}{ Determinants } & \multicolumn{3}{|c|}{ Income category } \\
\hline & Total & Farm & Non-farm \\
\hline AGE & $-0.4 \%$ ** & $-0.2 \%$ & $-0.2 \%$ \\
\hline MALES & $4.2 \%$ ** & $1.5 \%$ & $6.2 \%^{* *}$ \\
\hline FEMALES & $2.4 \%$ ** & $2.5 \%$ & $3.3 \% *$ \\
\hline SW & $-9.2 \%$ & $-5.9 \%$ & $-13.4 \% *$ \\
\hline PWD & $-6.0 \%$ & $1.6 \%$ & $-20.5 \%{ }^{* *}$ \\
\hline ELD70 & $-3.9 \%$ & $-6.8 \%$ & $-5.4 \%$ \\
\hline AGRILEASE & $-9.1 \% *$ & $3.4 \%$ & $-3.6 \%$ \\
\hline INSOURCE & $23.4 \%$ ** & $15.6 \%$ ** & $5.4 \% *$ \\
\hline LPG & $28.1 \%$ ** & $16.8 \%$ ** & $33.1 \%$ ** \\
\hline
\end{tabular}

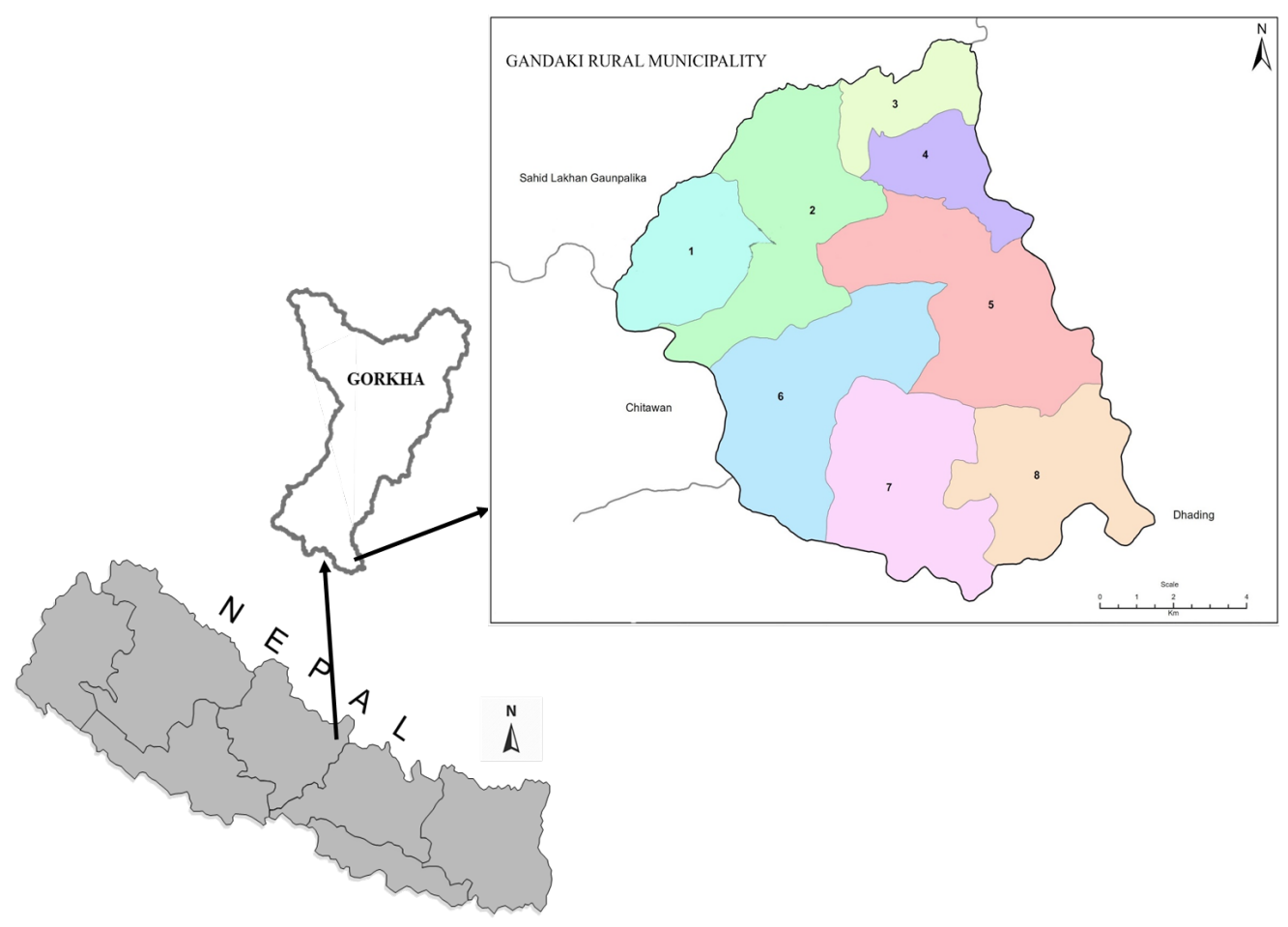

Figure 1. Location of the Study Area 